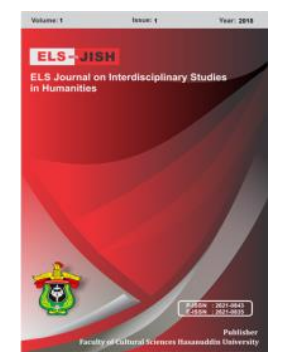

ELS-JISH

ELS Journal on Interdisciplinary Studies on Humanities

Volume 1 Issue 1, 2018

ISSN (print) : 2621-0843

ISSN (online) : 2621-0835

Homepage : http://journal.unhas.ac.id/index.php/jish

\title{
The Role of Inquiry Based Learning to Improve Reading Comprehension of EFL Students
}

\author{
Ermawati ${ }^{1}$, Nasmilah Yunus ${ }^{2}$, Abidin Pammu ${ }^{3}$ \\ E-mail of Corresponding Author: ermawatiherman088@gmail.com
}

\begin{abstract}
Approaches in reading have widely emerged to fulfill the needs of learners to comprehend a text and to change their reading habit which is one of them is Inquiry Based Learning (IBL). Thus, this study aims to identify the role of Inquiry Based Learning to improve reading comprehension. The design of this study was mixed method with QUAN-qual model. The quantitative method used quasiexperimental design with control and experimental group including pre-test and post-test. It used purposive sampling technique to determine the samples who involved 40 students; 19 students in control class and 21 students in experimental class. This study was conducted at third semester students of English Education Department of STKIP Muhammadiyah Sidrap. The data were gained through test and non-test (questionnaire and interview). Then, the data were analyzed through SPSS 22. The significant findings of the recent study was the roles of IBL; developing students' reading proficiency, engaging the students with complex texts, practicing students' all levels of comprehension as they take a part in IBL phases, activating students prior knowledge, aligning inquiry process to students' reading comprehension, providing students to work with team and enhancing students' learning process. Finally, this study could be implemented practically and pedagogically in the study of IBL.
\end{abstract}

Keywords: Text, Role, Inquiry Based Learning, Reading Comprehension.

How to cite: Ermawati, et al. (2018). The Role of Inquiry Based Learning to Improve Reading Comprehension of EFL Students. ELS-Journal on Interdisciplinary Studies in Humanities, 1(I), 13-20.

\section{Introduction}

Nowadays, reading is a very crucial tool for human empowerment. It is the basic skill to possess in order to comprehend the text. Medina (2012), stated that reading is one of the most frequently used language skills in daily life. Moreover, this reading becomes more inevitable in English as a foreign language class in order to learn how to comprehend in different languages.

The problem faced now by a teacher that the habit and interest of reading of Indonesian learner is very low. Bakar (2014), found out the a factor of low interest in reading that was the society did not like reading. This is such a kind of big obstacles for the teacher to teach reading in a classroom.

Nevertheless, for foreign language learners, they have to be well prepared to implement many kinds of abilities and strategies that they have already had in their reading experiences in their native language. The learners will need their prior knowledge to help

\footnotetext{
${ }^{1,2,3}$ Faculty of Cultural Sciences, Hasanuddin University
} 
ISSN: (E) 2621-0835, (P) 2621-0843

acknowledge themselves to many kinds of texts. Then, the act of reading is non-linear process that makes the readers tend to jump ahead or go back to different segments of the text, depending on what they are searching for in the text. The research on reading comprehension has revealed that reading is a complex cognitive process that is implicated to gain new knowledge and retrieve information on demand.

Considering the importance of teaching reading comprehension, methods and approaches have emerged widely to fulfill the needs of learners to comprehend a text and to change their habit in reading as well as to provide understanding about methods and approaches in order to gain the information from the text in general. In addition, some approaches are taken into account in order to enhance comprehension process. In the case of approach used in teaching, one of them is Inquiry Based Learning (IBL). Inquiry engages in questions that could be easily interpreted as simply "asking questions". Also, Lee (2014), categorized IBL as pedagogical approach as well as a learning strategy. By applying questioning, the core value of Inquiry Based Learning is to emphasize discovery learning and the development of cognitive skills and metacognitive strategies. Also, Blessinger \& Carfora (2015), noted that the goal of this approach is to change the learner learning from passive participation to become active participation.

Furthermore, Gonzalez (2013), found out the way to design a course that invites undergraduate students to become more critical, complex and autonomous learners that is by using IBL approach. This identifies one of the roles of IBL.

Additionally, Lee (2014), explained this prominent model has been applied to the teaching in science and math, whose model concept and question-answer mechanism are equally well-suited to L2 classroom. This shows that the instructional model is primarily used in teaching science and math. In addition, the BSCS 5E model which is grounded in sound educational theory, has a growing base of research to support effectiveness, and has had a remarkable impact on science education (Bybee et al., 2006). Also, Rooney (2012), affirmed that her students became more engaged in the inquiry-based learning process as asking, researching and answering the question of "how is IBL used to improve practice and encourage the higher thinking among students of mathematics". This emphasizes the use of $\mathrm{IBL}$ in math classes to promote the higher order thinking.

However, previous research on IBL has tended to focus on the use of IBL to teach math and sciences rather than on language. Therefore, the sole objective in this paper is to find out the role of Inquiry Based Learning to improve reading comprehension.

\section{Method}

This part explains about the methodology of the research in specific. This study was applied mixed method design by combining quantitative and qualitative design.

\subsection{Location and Research Design}

The research took place at STKIP Muhammadiyah Sidrap of the third semester students. This study implemented mixed method; QUAN-qual model. The quantitative method used quasi-experimental design which had control and experimental groups. This was to identify whether or not the use of IBL was able to provide significant difference between control and experimental groups.

\subsection{Subject}

There were 40 students for two classes; 21 students in experimental class and 19 students in control class. The sample was taken by purposive sampling technique that is the researcher kept the existing classes.

\subsection{Data Collection}

The data were gathered through test and non-test instrument. The non-test was using 
questionnaire and interview. The test was taken from practice samples of reading IELTS test. While, the questionnaire was adapted from Edx online course. Whereas, the interview was given along with the questionnaire which comprises three questions. Furthermore, the ways to collect data were giving pre-test, treatment, and post-test as well as asking students to fulfill the questionnaire and answering the interview.

The treatment using IBL approach was served to experiment class while the control class was taught by using conventional way. Treatment was implemented in 5 meetings for each class. One meeting took 90 minutes. The procedures of doing treatment as follows: The students were taught by applying the principles of Inquiry Based Learning with 5E Instructional model: engagement : teacher asked the class about their previous knowledge about the theme of reading. The teacher also asked them to discuss in pair about the theme. The teacher invited one or more students to explain what they knew about it. Exploration : teacher let students to read a passage. Then, they were splitted to be in group of four or five students in a group and let them find the content of the passage together with their group. In this part, the teacher provided a strategy to master the reading text. It was given in question form to enable them to find out the answers in group. Explanation : students were required to explain the content of the reading by their own words and based on their discussion. Elaboration : students worked together to answer some questions provided then. Evaluation : the teacher provided a carton to be stuck. The students stuck a sticky note about a new vocabulary they got from the passage and wrote their opinion about the learning process of the day.

\subsection{Data Analysis}

To analyze the data, some statistical formula were applied by using SPSS 22 program. It was started by counting the score of reading test by referring to IELTS nine-band scale. After that, the program was run to find out the mean score, frequency, reading achievement of control and experimental group, then to determine the ranks of progress in both groups. Next, the questionnaire frequency of each item was splitted to investigate the comments on the IBL approach using Likert scale. Finally, the interview was analyzed.

\section{Findings}

There were three kinds of technique of collecting data: test, questionnaire, and interview. Based on these techniques, the findings were divided into three parts. Firstly, finding through test. In test, the result of reading test was differentiated based on the class: control and experimental class. The Mann Withney $U$ was applied to find out the significant difference between scores of both classes. The result was determined in table 1.

Table 1. Mann-Whitney $U$ test of experimental group

\section{Test Statistics $^{\mathrm{a}}$}

\begin{tabular}{lr}
\hline & Post-test \\
\hline Mann-Whitney U & 39.000 \\
Wilcoxon W & 229.000 \\
Z & -4.443 \\
Asymp. Sig. (2-tailed) & .000 \\
Exact Sig. [2*(1-tailed Sig.)] & $.000^{\mathrm{b}}$ \\
\hline
\end{tabular}

a. Grouping Variable: kelompok

b. Not corrected for ties.

The table shows that probability value is 0.000 which is the rule is if the probability value (Asymp. Sig) is less than $5 \%$ at the level of the significance $0.05(\mathrm{P}<0.5)$, it means that it has significant difference. Furthermore, the result of Asygmp. Sig is 0.000 which is less 
ISSN: (E) 2621-0835, (P) 2621-0843

than the significant level of 0.05 ( $\mathrm{P} ; 0.000<0.05)$, so that it indicates that $\mathrm{Ha}$ is accepted. The description reveals that there is a significant difference between control and experimental group score. The explanation means that the use of IBL has provided a role for the improvement of the experimental class score which is given a treatment by applying IBL approach.

After that, the ranks of both classes were sought to present the difference of the achievement of both classes. Simply, the rank test determines the participants which have negative ranks, positive ranks, and in tie ranks. A participant with negative rank means the person has decreased score from post-test to pre-test. The participant with positive rank means the person has improved in the post-test score comparing with the pre-test. Moreover, the participant in tie rank means the person does not have any decrease or increase or their rank is stagnant, in other words, it has same score between post-test and pre-test. The rank of control and experiment group was given in table 2 and 3.

Table 2. Wilcoxon Signed Ranks Test of control group

\begin{tabular}{llrrr}
\multicolumn{5}{c}{ Ranks } \\
\hline Post-test - Pre-test & N & Mean Rank & Sum of Ranks \\
& Negative Ranks & $6^{\mathrm{a}}$ & 6.33 & 38.00 \\
& Positive Ranks & $7^{\mathrm{b}}$ & 7.57 & 53.00 \\
& Ties & $6^{\mathrm{c}}$ & & \\
& Total & 19 & & \\
\hline
\end{tabular}
a. Post-test $<$ Pre-test
b. Post-test $>$ Pre-test
c. Post-test $=$ pre-test

Table 3. Wilcoxon Signed Ranks Test of experimental group

\section{Ranks}

\begin{tabular}{llrrr}
\hline & & N & Mean Rank & Sum of Ranks \\
\hline Post-test - Pre-test & Negative Ranks & $1^{\mathrm{a}}$ & 11.00 & 11.00 \\
& Positive Ranks & $19^{\mathrm{b}}$ & 10.47 & 199.00 \\
& Ties & $1^{\mathrm{c}}$ & & \\
& Total & 21 & & \\
\hline
\end{tabular}
a. Post-test $<$ Pre-test
b. Post-test $>$ Pre-test
c. Post-test $=$ Pre-test

Comparing both results of the Wilcoxon Signed Ranks Test of control and experimental group, it could be inferred that there are 19 students of experimental group have improved of the score while only 7 students of the control group have performed better at reading achievement after being taught without using IBL. Similarly, the IBL improves students' reading achievement of the participants in experimental group by looking at the statistical results of some tests of SPSS applied.

In findings through the questionnaire, some numbers of questions were agreed by most of the participants. They were item 1 "I found this course to be well organized which were chosen by 12 students, item 4 "I learned a great deal about the subject matter, chosen by 10 students, item 5 "completing the assesment work helped me learn, selected by 9 students, item 6 "comments and feedback I received helped me learn more effectively, chosen by 10 students and item 9 "Overall, this was a good quality course" selected by 12 students. 
Ermawati. 1(1): 13 - 20

At last, the interview result showed several results: the question "what has helped your learning in this course?", most of participants stated that it had sharing group, and followed by statement "it helped me to read a lot, because it had tricks in reading. Second question was "what has hindered your learning in this course?", it was answered "there was much voice heard outside" and "I did not focus and I was still lack of vocabulary"by a lot of participants. The last question "do you have any suggestions for improving course?" which most of them answered that the class should have been provided by some games or other icebreakers.

\section{Dsicussion}

The result of the finding of the research shows that the result of the Asygmp. Sig is 0.000 which is less than the significant level of 0.05 (P; $0.000<0.05)$. It means there is a significant difference between control and experimental group scores and between experimental group pre-test and post-test. It indicates the IBL is able to improve reading comprehension. Similarly, this presents that the implementation of IBL provides big roles to improve the students' reading comprehension.

The finding section has supported some previous related studies. In general, Inquiry Based learning is ideal for teaching reading class of sophomore students, especially with adult learners. The lecturer sets up the tasks and facilitates (Spronken-Smith, 2008), while students build on their existing knowledge. Inquiry Based Learning supports and stimulates students to pursue areas of interest to them (Martinee-Lee \& Duncan, 2015).

Based on the implementation of Inquiry-Based Learning in the experiment class for several meetings, then it is found some roles of Inquiry Based Learning toward reading comprehension. Firstly, it develops the students' reading proficiency by aligning selected reading strategies in specific phases of the Inquiry-Based Learning. When applying IBL, five phases are conducted for each meeting. By providing the text to be explored for each meeting, it sustains the students to enhance their reading proficiency. Then, it enables students to engage with increasingly complex and identify evidence from texts to support their interpretations. As long as the implementation of IBL approach, students are engaged with texts throughout the inquiry process (Spronken-Smith, 2008). Especially in explanation phase, the students are asked to explain what they have got in exploration phase. Once they try to answer the formulated questions, they should show the evidence of their answer from the text to support their interpretation about the text.

Furthermore, learners practice all levels of comprehension (literal, inferential, and critical comprehension) as they take a part in each phase of IBL (Sagita, 2015; Bybee, et al., 2006). There are three levels of comprehension (Hutura, 2016). The first level is literal or factual comprehension. This refers to the simple understanding of the information that is explicitly stated in the text. In exploration phase, students are led to read and comprehend the text by formulating questions which are aligned with the strategies provided for each meeting. Then, the second level, inferential comprehension, refers to information that relies on information that is implied, or not explicitly stated in the text. This is practiced in the elaboration phase which the students are given some questions related to the reading and let them answer the questions in which most of questions are testing their comprehension. The third level, critical or evaluative comprehension, involves the reader making judgments about various aspects of the text that is the literary quality of the text, the competency of the author, the righteousness of the characters and their actions, and so on. In evaluation phase, the students are given chance to write their comment about the text on the carton provided on the whiteboard. This approach enables the levels of comprehension to emerge in the process of comprehending the text.

Then, the learners are supported to activate or build their background knowledge as they take a part in engagement process which also merits with top-down process. This is along with this IBL that improves the engagement of the students by increasing the students ability to reason and problem solve. This supports the finding of Maxwell et al (2015). While, 
ISSN: (E) 2621-0835, (P) 2621-0843

this helps individual to question, make predictions, and draw inferences (Moreillon, 2014). Also, it follows one of the five learning pathways, that is when they draw the inferences at the same time they are trying to give propositions (Steele et al., 2016) toward the reading text. Next, it aligns the inquiry process to reading comprehension strategies and learning applications to define learning goals (Pinard \& Herman, 2015). Because of the 5E learning cycles, the teacher has the perfect opportunity to combine some interconnected strategies to improve reading comprehension (Ness, 2009). In the exploration phase, the teacher provides the strategies to master in order to comprehend the text.

Then, it provides the students to work with team (Ajit et al., 2014; Pinard \& Herman, 2015). To support the inquiry process, working in group become a good strategy to apply in which students can share the ideas, the knowledge and their predictions about the text. Work with team also leads the sudents to be more collaborative, which is according to Sangra et al (2015), found out that IBL has its great component of collaborative learning, since it provides the students to actively participate in the class. Also, by working with team, they could be actively engaged in the discussion and in the process of answering the questions. Similarly, Rahaman (2014), reported the group work provided in the strategy applied in this approach brings about the students to be more concious and understanding the text that creates an interesting and free environment. Finally, IBL directs the students to enhance the learning of the process of comprehension faster (Moreillon, 2014; Martinee-Lee \& Duncan, 2015). The learning process is well organized so that the process of comprehension can be fostered while providing some strategies to possess. Five kinds of process involved in the approach activate the students' reading process. Accordingly, it merits with Lu \& Singman (2015), finding that students in IBL stages become involved in the thinking processes to evaluate the information resulting in insight and deep understanding connected with the topic.

The students' perception is gained from the questionnaire given and the free-interview. From the finding of the questionnaire, some respons toward the implementation of IBL are explained briefly. Firstly, the students think this course is well organized. This is proved by the questionnaire that there are twelve persons or more than a half of students think this course is well organized. Furthermore, this course has its own stages to follow, so that it enable the teacher to arrange the course well by paying attention on the stages and the limited time for each stage. Secondly, they believed they learned a lot from this course about the reading materials. The most choice of this perception is neutral and agree position. It means, some students think they sometimes learned a lot from this course and also, some people think they learn a lot from this course about reading. It shows that several students believe they learn a great deal about the subject, in other time, the others do not learn a lot from this course.

Then, they are helped through completing the assessed work. Most of students think the completing assessed work helps them in learning about passage. It is shown by the questionnaire that is chosen mostly in agree position. It is also backed up by the free answer written interview that is written by respondent 013 , that $\mathrm{s} /$ he loved doing the assignment. Furthermore, they learn more effectively from the comments and feedback they gain from the class. In this comment, a highest numbers of students choose to agree about the comments and feedback they receive help them learn more effectively. This propounds that the role of the teacher in some stages as the facilitator has helped them learn more effectively. It is also supported by the comment of respondent 016 who stated that the explanation after giving test helps him/her in learning. Next, the quality of teaching in this course is good. This course instills value for multiple ways of learning so that they think this as a good course. It is proved by the item 9 of the questionnaire "overall, this was a good quality course", which is chosen by 12 persons or more than a half of the respondents. This recounts that this IBL is a good approach to apply in reading course.

Finally, this course helps them to learn the strategies in comprehend the passage. Through the free-interview answered by writing, the students think this course helps them to 
Ermawati. 1(1): 13 - 20

be more diligent in reading because it is sustained by the tricks of reading passage which aare actually the strategies applied to comprehend the text that is also covered by the use of IBL. It is stated by most of the respondents in the question "what has helped your learning in this course". Most of students answered because it had sharing group, then some students stated "it helped me to be diligent in reading, because it has tricks for mastering passage.", while others jotted down that they liked the methodology of learning, they liked to do some assignments, they like to search for new vocabularies, and the explanation after the test given.

\section{Conclusions}

This study comprises two main points: the role of Inquiry-Based Learning to reading comprehension and the students' perception toward the implementation of IBL. Firstly, the roles of Inquiry-Based Learning are that students develop reading proficiency, engage with complex texts, practice all levels of comprehension as they partake in IBL phases, align inquiry process to reading comprehension, provide to work with team and enhance learning process. Finally, the students' perception toward the implementation of Inquiry Based Learning are found after applying this IBL in reading context. Several comments on it are this course is well organized, the learners learn a lot about the text, they are helping complete the work, they learn from the comments and feedback given by the lecturer, this course has good quality and they learn the strategies to comprehend the text that help them much in the learning process. Also, the writer sustains to carry out research of IBL on another skills in learning English language: listening, speaking or writing to explore IBL whether it is suitable for all kinds of skills. Also, this study provides a new insight for readers to skills of learning language especially reading comprehension. Finally, it is a beneficial approach to implement in language learning context in receptive skill in specific.

\section{References}

Ajit et al. (2016). Higher Order Thinking Skills through Online Discount Coupons. Journal of Recent Research and Applied Studies. 3(5): 71-74.

Bakar. (2014). Faktor - faktor Penyebab Rendahnya Minat Baca Masyarakat di Taman Baca Masyarakat. Unpublished thesis. Bengkulu:Bengkulu University.

Blessinger \& Carfora. (2015). Innovative Approaches in Teaching and Learning: An Introduction to Inquiry-Based Learning for Multidisciplinary Programs. Innovations in Higher Education, 3: 3 -22.

Bybee et al. (2006). The BSCS 5E Instructional Model: Origins and Effectiveness. BSC.S: Colorado.

Gonzalez. (2013). My Journey with Inquiry-based Learning. Journal on Excellence in Cc. ${ }^{8}$ _e Teaching, 24(2): 33-50.

Hutura. (2016). Literal, Inferential and Critical Reading Comprehension. Accessed at $1^{\text {st }}$ March 2017. Available from: https://owlcation.com/academia/Literal-Inferential-andCritical-Comprehensive-Reading.

Lee. (2014). Inquiry-based Teaching in Second and Foreign Language Pedagogy. Journal of Language Teaching and Research, 5(6): 1236-1244.

Lu H. \& Singman C. (2015). Enhancing Inquiry-Based Language Learning with Educational Digital Library. Journal of Education and Training, 2(1): 48-60.

Martinee-Lee \& Duncan. (2015). A Master's Level Research Methods Class: A Practice Example of Inquiry-Based Learning. Innovations in Higher Education Teaching and Learning, 3:173 - 189.

Maxwell et al. (2015). Effects of Using Inquiry-Based Learning on Science Achievement for Fifth-grade Students. Asia-Pacific Forum on Science Learning and Teaching, 16(1).

Medina. (2012). Effects of Strategy Instruction in an EFL Reading Comprehension. Profile Journal. 14(1): 79-89.

Moreillon. (2014). Inquiry Learning and Reading Comprehension Strategy Instruction: Processes that Go Hand in Hand. Knowledge Quest, 43(2): 1-4. 
ISSN: (E) 2621-0835, (P) 2621-0843

Ness. (2009). Reading Comprehension Strategies in Secondary Content Area Classrooms: Teacher Use of and Attitudes towards Reading Comprehension Instruction. Reading Horizons Journal, 55(1): 59-85.

Pinard \& Herman. (2015). Critically Examining Inquiry-Based Learning: John Dewey in Theory, History and Practice. Innovations in Higher Education Teaching and Learning, 3: $43-62$.

Rahaman A. (2014). Reading Comprehension through Group Work Activities in an EFL Clasroom: An Action Research Report. Working Papers on Culture, Education, and Human Development, 10(2):1-18.

Rooney. (2012). How am I Using Inquiry-Based Learning to Improve my Practice and to Encourage Higher Order Thinking among Students of Mathematics. Educational Journal of Living Theories, 5(2): 99-127.

Sagita. (2015). The Implementation of Scientific Approach in English Teaching through Inquiry Based Learning in the First Year at SMP N 1 Purwodadi in 2014/2015 Academic Year. Journal of Department of English Education, School of Teacher Training and Education of Muhammadiyah University of Surakarta.

Sangra et al. (2015). Connecting Inquiry-Based Learning with Collaborative Work in Online Education. Innovations in Higher Education Teaching and Learning, 3:211 - 232.

Spronken-Smith. (2008). Experiencing the Process of Knowledge Creation: The Nature and Use of Inquiry Based Learning in Higher Education. (Journal). 1-15.

Steele A. et al. (2016). Stories of Learning: Inquiry-based Pathways of Discovery through Environmental Education. Cogent Education, 3: 1-17. 